\title{
Regional government concerns in health services in remote areas: Case study on special capitation policies in North Bengkulu Regency
}

\author{
Try Purnamasari ${ }^{1 *}$, Diah Ayu Puspandari ${ }^{1}$, Mubasysyir Hasanbasri ${ }^{2}$, Firdaus Hafidz ${ }^{1}$, and Muttaqien Muttaqien ${ }^{3}$
}

${ }^{1}$ Health Financing Policy and Insurance Management Studies, Department of Health Policy Management, Faculties of Medicine, Public Health and Nursing Universitas Gadjah Mada, Indonesia

${ }^{2}$ Biostatistic, Epidemiology and Population Health Studies, Department of Health Policy Management, Faculties of Medicine, Public Health and Nursing, Universitas Gadjah Mada, Indonesia

${ }^{3}$ Center of Health Financing Policy and Insurance Management Studies, Department of Health Policy Management, Faculties of Medicine, Public Health and Nursing, Universitas Gadjah Mada, Indonesia

\begin{abstract}
The Minister of Health Regulation No. 52 of 2016 states that the tariff for first-level health services in remote areas and islands is determined based on special capitation tariffs, which is greater than the usual capitation tariffs. In North Bengkulu there is a primary health care that does not include a special capitation even though the criteria are the same as the primary health care that received it. The perception of stakeholders involved is needed to see whether the determination of criteria for disadvantaged areas for recipients of special capitation funds is in accordance with existing regulations or not. The study was based on in-depth interviews with 6 respondents from 6 institutions (Local Government, Regional Secretary, Health Office, the BPJS health branch office, and two Primary health care). The local government does not help question that matter to BPJS or help in other ways so that health care that do not receive special capitation funds can still provide optimal services like other remote health care. This study found the lack of socialization about health services in remote areas to non-health officials in local governments is the causes of weak support by local governments. This research shows that the application of central policies without joint review and verification with local stakeholders can lead to unproductive situations. Local governments should also look for solutions so that health care in remote areas that do not receive special capitation funds continue to run optimally.
\end{abstract}

\section{Introduction}

In Indonesia, capitation funds for payment of health services are obtained from premium JKN participants who partially pay for health services through capitation. The Indonesian National Health System does indeed mention the payment of health for private payments, except for the poor who pay the government [1].

One of the health facilities that can be paid for by the capitation system is the Primary health care [2]. The Minister of health Number 90 of 2015 composes in terms of addressing the balance of health care in a safe and very complicated health facilities. New policies are made, namely on health management in health facilities. The purpose of the discussion in article two is one of increasing the accessibility of health services in very complex discussion areas. a special program to improve the implementation of the Health Insurance program by implementing a special capitation payment system for the regions and very useful [3].

Based on the Minister of Health Regulation No. 52, 2016 states that the price of special tickets for Primary health cares owned by doctors is set at ten thousand rupiahs per participant per month, for Primary health cares which only offer midwives/nurses is set at IDR 8000 percentage per participant per mon. In the number of participants in the primary health care less than one thousand participants, the special rate agreed to in paragraph one is approved by the minimum number of participants for one thousand participants. The additional provisions in the Minister of Health Regulation also include the requirements for determining primary health care for the approved regions, which are very difficult and not desirable, must be based on a decree from the regional head. Changes in the mechanism of payment from the fee for service form to the prospective payment system include capitation [4]. At present, special capitation rates based on December 2017 data are carried out in 19 districts/cities with 131 selected Primary health care according to the Permenkes criteria [5].

Some of the regulations or policies made are intended for the prosperity of the people to get a better life, especially in matters of access to health services. The policy itself involves many aspects so that it can be implemented properly, such as the stakeholders

* Corresponding author: purnamatry3@gmail.com 
involved to accept and implement the policy. The new policies implemented in the regions are very dependent on stakeholders in responding, so making this policy is unnecessary and can be done properly. A stable system requires work among stakeholders, namely in terms of requesting new policies, payment systems, special capitation for the regions, as well as involving stakeholders such as local governments, Regency/City branch BPJS, Health Office and Primary health care [6].

In Bengkulu province, the region received a special payment policy in North Bengkulu Regency, where the area had geographical policies compared to other districts. In North Bengkulu, the type of system that is applied to the least developed regions is only in three Primary health care, where three Primary health care have a considerable distance from each other. New policies such as a special payment system for disadvantaged regions require additional cooperation, both from within and outside the Primary health care, so that the expected results from the implementation of new policies can be implemented well.

In a preliminary study conducted by researchers to several sources such as the Head of the North Bengkulu Health Office and regional government offices, it was found that there was an information gap between the two, namely according to the North Bengkulu District Health Office that there was still one community health centre that had the same criteria as the Primary health care those who get special capitation payments but have not even been included in one of the recipients, namely having an area far from the district/city centre, geographical areas are even more severe when compared to Primary health care that has received special capitation payments.

\section{Materials and methods}

\subsection{Samples}

In this study, researchers extracted information from several informants. The Informant is someone who knows a particular problem or problem from which can be obtained clear, accurate, and reliable information in the form of statements, statements, or data that can help in understanding these problems or problems. In this study, the informant retrieval technique used by researchers was purposive sampling. This informant retrieval technique is based on the tendency of researchers to choose informants who are considered to know information and problems in-depth and can be trusted to be a good data source.

The inclusion criteria in this study were: people who were directly involved in implementing the new special capitation system policy. The people who are the subject of research are: Secretary of North Bengkulu Regency, Local government (regional planning and development agency), Head of the Health Office, Branch Head of North Bengkulu Regency BPJS, Head of the White Napal Health Centre, Head of Tanjung Harapan Health Centre

\subsection{Methods}

In this study, researchers used a type of descriptive research with qualitative methods. Researchers in this study analysed stakeholder perceptions of the criteria for determining the remote areas of special capitation recipients. In order to complete descriptive sharpening, a search for documents held by stakeholders is also carried out [7].

The location or place in this study is at North Bengkulu Regency. The people who were the subjects of the study were the Regional Secretary of North Bengkulu Regency, Bappeda (Local Government), Head of the Health Office, Branch Head of North Bengkulu Regency BPJS, Head of the White Napal Health Centre and Head of the Tanjung Harapan Health Centre.

\subsection{Data analysis}

The approach of this research is qualitative research, where questions are asked openly, analysis and classification of answers given interactively, namely after the data collected is summarized, coding and making footnotes, discarding unnecessary and then data is presented in the form of narrative text. To guarantee data validity, triangulation is carried out. At the end, a conclusion will be drawn. Then analysed manually by going through the following stages: After the data is collected, it starts by examining all the available data from various sources, namely from the results of indepth interviews and document studies. Data reduction by making abstractions, namely making a summary that is in accordance with the data studied. Data is arranged in the form of information, then coding. Data category is to group data according to the variables needed. Data that has been grouped will be analysed and presented descriptively. Then data analysis is carried out, namely the process of simplifying data into a form that is easier to read and interpret. In this study qualitative data was analysed by reading line by line, given a code, and searched the essence of the data. Data analysis was carried out together with data collection, literature review and conclusions [8].

\section{Results}

\subsection{Stakeholder knowledge about determining criteria for remote areas}

The first thing that was reviewed was that stakeholders knew that to become a special capitation recipient health centre had certain criteria. This can be seen from the statement as follows:

"For the Napal Putih district itself, including remote areas because we also have areas that are far from city, our target area in Lebong Tandai village, which is indeed very remote, is needed more than $8 \mathrm{~h}$ to get in the city" (R6) 
"There are those who are remote and very remote, and the islands may be very remote, only if the Napal Putih areas can be said to be remote because of its distance from the capital." (R1)

Based on the statement, it was found that the knowledge of stakeholders originating from the government did not clearly understand what the criteria referred to in the regulations regarding remote area determination policies. This can be seen from statements that are only general in nature and do not lead to what the intended criteria are, in contrast to stakeholders from health institutions who can explain in more detail the intended criteria.

\subsection{Stakeholders' attitudes toward new policies special capitation systems}

Some things that are seen are how the stakeholders respond to these policies and how they respond to special capitation areas, which can be seen from the following quote:

"Yes it's relative, we just have to see how to judge it. Just in general, that's enough, but we hope we have to increase it more." (R1)

"So, if we just follow the application, the regent's statement is there, so if we already have it, we just have to go ahead, right, the BPJS is only the purchaser, yeah, the one who pays is .." (R3)

"For special capitation, I think it is appropriate, because if it seems like it will be more complicated than it is clear that our funds have a health centre giro account, BPJS transfers to the Primary health care account, we use it according to the existing rules, right away even though there are new rules from the local government, we still follow them.” (R6)

From the results of the study, it was found that the attitude shown by respondents to this new policy was very supportive, which was seen from respondents who stated that the support was given in accordance with their respective fields. As explained by informants from the local government, if the policy is made for the welfare of the community, so if there are still problems such as areas that are not included in the special capitation recipient, it will be studied so that it can be followed up quickly to support community welfare, if indeed still remote, it will be fought for, but if it is more likely to be a more developed village, it will be developed as a new growth centre. This is in accordance with the Decree of the Village Minister, Development of Disadvantaged Regions and Transmigration concerning the establishment of seventeen thousand priority villages targeted by rural development, development of disadvantaged areas and transmigration, although the criteria for determining priority villages differ from the minister of health regulation criteria for special capitation recipients, but at least the regional government can continue to develop potential areas.

\subsection{Experience of stakeholders on policy determination}

The experience in this study is the experience experienced by respondents in their participation in the determination or implementation of new policies. This can be seen from the following statement:

"If I make a policy, I mostly only revise the old policy, I participate in the meeting if needed. But for the new policy, this is still the latest, this particular capitation." (R1)

"We only accept the policy and socialize it, most of the regional policies are determined by the regent, so we don't participate." (R2)

“... We are a small Community Health Centre, I have never determined a policy, I will accept it at the very least, like this special capitation, there is news, the decree is issued, we accept it." (R5)

From the statement above, it was found that most stakeholders claimed not to be directly involved with the formation of new policies, namely because most of the stakeholders who were respondents were not all involved in the world of government. The existence of new policies recognized by respondents is the special capitation policy itself, where the determination of criteria still uses existing criteria and areas that have been previously set and there has been no renewal.

\subsection{Stakeholder expectations of the new policy of the special capitation system}

In this study, the intended hope is the respondent's desire for the implementation of a new special capitation policy, in general expectations of the informants can be seen through the following in-depth interviews:

"The hope is that the implementation of this policy will be carried out well, yes, there are no frauds or mistakes that cause harm to health workers and their people" (R1)

"The expectation is that there are no obstacles in the implementation, it can be implemented well and smoothly, so doctors and midwives can receive capitation rates specifically in accordance with those set for remote areas." (R4)

Based on the results of in-depth interviews conducted, it can be seen that the informants on average have high expectations about the new policy of this particular capitation system. As seen in quote R1 and R2 which are informants from local government agencies also expect the best to advance the health aspects in their area. 


\subsection{Stakeholders' interest in new policies for special capitation systems}

In this study, the intended interest is the frequency of respondents participating in and contributing to the policy regarding the criteria for determining specific areas of the recipient of capitation. What was seen was about who benefited the most from the adoption of a new special capitation system policy, as described in the interview as follows:

"Well the Primary health care still will have the benefit, because this special capitation rate is intended for the welfare of the Primary health care officers." (R1)

"There is an officer who gets a rate higher than the usual capitation rate." (R3)

"The ones who benefit most from the officers of the Primary health care and the Primary health care, because they will be given a bigger rate, will make the Primary health care better." (R4)

"Because the target is us, remote health centres, then of course we will have the benefit" (R5)

Based on the results of in-depth interviews conducted with informants, it was found that four informants agreed that those who benefited the most from the implementation of this special capitation funding system policy were health workers at the Primary health care, although the informants did not specify in detail who the officers were. While the other two informants stated that only overall, the Primary health care were the ones who got the most profits.

\subsection{Accuracy of criteria for special capitation recipient areas}

A criterion is considered appropriate if it is in accordance with the measure, in this case, that is, concerning remote areas for special capitation recipients. The criteria for Primary health care receiving special capitation funds are regulated in minister of health regulation No. 90 of 2015 and regent's statement of North Bengkulu Regent Number 440/160/health local ministry/2016.

The accuracy of the criteria according to stakeholder perceptions, in this study, is seen from the point of view of the local government and the health sector, some consider that the criteria used are appropriate, only a few health sector stakeholders respond that it would be better to have a number of criteria eligible recipients can participate in the special capitation funding. Based on Presidential Regulation number 131/2015 concerning Determination of Disadvantaged Regions in 2015-2019, states that Disadvantaged Regions are districts whose regions and communities are less developed compared to other regions on a national scale. An area is defined as a lagging area based on the following criteria: community economy, human resources, facilities and infrastructure, regional financial capacity, accessibility and regional characteristics.

\section{Discussion}

\subsection{Stakeholder knowledge about determining criteria for remote areas}

The knowledge of stakeholders in the health sector is said to be good then it can be seen from the results of interviews which say that the informants knew that the target area or work area they sheltered was indeed very remote, because reaching the area required up to eight hours of land travel. Policies are often interpreted as decisions made by those who are responsible for certain policy areas. Policies can be arranged in all structures, central or regional governments, multinational companies or regions, schools or hospitals. Published health policies regarding public policy and health regarding health protection include actions that affect relationships, organizations, services, and health system planning efforts [9].

This is in accordance with Minister of Health Regulation No. 90 of 2015 concerning the implementation of health services in health facilities in remote and very remote areas, mentioned in the criteria for remote and very remote areas point five which states the round-trip distance from the district capital using routine public transportation (land/water) takes more than $6 \mathrm{~h}$. Where the points get a score of two, which is a higher score and a priority among others, which determines the assessment of the criteria. So that from the interviews that were obtained and direct observations made by the researchers, it was found that the existence of these remote places was true.

\subsection{Stakeholders' attitudes toward new policies special capitation systems}

From the results of the study, it was found that the attitude shown by respondents to this new policy was very supportive, which was seen from respondents who stated that the support was given in accordance with their respective fields. As explained by informants from the local government, if the policy is made for the welfare of the community, so if there are still problems such as areas that are not included in the special capitation recipient, it will be studied so that it can be followed up quickly to support community welfare, if indeed still remote, it will be fought for, but if it is more likely to be a more developed village, it will be developed as a new growth centre. This supportive attitude is also important for health workers to have, which is in line with the results of research conducted by 2 which states that the percentage of capitation income paid to doctors does not have an influence on the performance of doctors, but through attitude as an intermediary variable.

\subsection{Experience of stakeholders on policy determination}

The results of the research reveal that the experience of the respondents was in the poor category, which can be seen from the results of interviews which stated that the 
respondents were not directly involved with the formation of new policies, this was also because not all respondents came from the government. Nonetheless, respondents also stated that they were involved in the acceptance of the policy, namely implementing in accordance with the provisions of the policy. For the new policy, all respondents acknowledged that there were not many new policies established, the health payment policy with this special capitation system was considered the most recent.

\subsection{Stakeholder expectations of the new policy of the special capitation system}

Based on the results of in-depth interviews conducted, it can be seen that the informants on average have high expectations about the new policy of this particular capitation system. As seen in quote R1 and R2 which are informants from local government agencies also expect the best to advance the health aspects in their area. Capitation changes everything in health care, namely from access, quality and profitability. Most importantly, this challenge traditional concepts of patient care, physician autonomy, and accountability [10].

\subsection{Stakeholders' interest in new policies for special capitation systems}

Based on the results of in-depth interviews conducted with informants, it was found that four informants agreed that those who benefited the most from the implementation of this special capitation funding system policy were health workers at the Primary health care, although the informants did not specify in detail who the officers were. While the other two informants stated that only overall, the Primary health care were the ones who got the most profits.

It can be seen from the interview results presented in the results of the study, respondents from health agencies explained that there was one area that also deserves special capitation, but on the other hand government stakeholders explained that all policies had been carried out in accordance with existing regulations, but the informant also explained that does not rule out the possibility of revising policies if necessary.

In this special capitation funding system policy is given directly to the Primary health care account that receives special capitation, so that there is no payment relationship with the region or the health service, so that fraud can be minimized, as in Koduah's research which states that political interests often times become obstacles in the implementation of new policies, access to political power and the power of bureaucrats becomes the opposite so that it triggers conflict which ultimately rejects various aspects of policy for primary health services [11].

\subsection{Accuracy of criteria for special capitation recipient areas}

The accuracy of the criteria according to stakeholder perceptions, in this study, is seen from the point of view of the local government and the health sector, some consider that the criteria used are appropriate, only a few health sector stakeholders respond that it would be better to have a number of criteria eligible recipients can participate in the special capitation funding. Based on Presidential Regulation No. 131/2015 concerning Determination of Disadvantaged Regions in 2015-2019, states that Disadvantaged Regions are districts whose regions and communities are less developed compared to other regions on a national scale. An area is defined as a lagging area based on the following criteria: community economy, human resources, facilities and infrastructure, regional financial capacity, accessibility and regional characteristics.

This is in line with the results of research conducted by Kullberg, Blomqvist and Winblad, which states that health services in rural and urban areas face different challenges [12]. Based on the research they conducted in Sweden, there were difficulties in introducing market dynamics in the provision of health services in rural areas, because these reforms not only damaged existing resource allocation systems based on health needs but also weakened the efforts of local policy makers to regulate health care provision in remote locations. So it does require a separate policy to continue to uphold equality in access to health care.

\section{Conclusion and recommendation}

This study shows the response of unproductive local stakeholders when there is no satisfactory explanation about the primary health care that did not obtain it but were considered worthy of receiving a special capitation policy. The regional government should be able to facilitate the ministry of health, the health department and BPJS so that there is a shared understanding of the implementation of central policies in the regions. When deciding on a special capitation recipient health center based on the Ministry of Health's about remote area status, BPJS needs to conduct a joint review with local stakeholders. Determination of central policies in the regions requires review and verification between central and regional stakeholders so that dynamic field conditions can be taken into account outside the remote area status set by the Ministry of Health.

Based on the results of the research that have been analysed, the conclusion can be drawn from this study stakeholders' perceptions of knowledge, attitudes, experiences, expectations and interests are good. Stakeholders who have the best knowledge and attitude are health sector stakeholders. Lack of experience from stakeholders in determining policies is not an obstacle to the implementation of special capitation policies. The different fields of stakeholders are the determining factors that the most benefited from this special capitation policy are health sector stakeholders.

The state of the Primary health care that receives special capitation in accordance with the criteria of the remote areas that have been determined. The suggestion that can be conveyed by researchers in this study is that the implementation of new policies really requires coordination from all parties, for that the regional 
government as the authorized stakeholder would be better if more implemented with more detailed socialization with other agencies related to the policy so that it does not happen wrongly understanding between them.

\section{References}

1. Menteri Kesehatan Republik Indonesia. Peraturan Menteri Kesehatan Republik Indonesia Nomor 12 Tahun 2016 Tentang Perubahan Atas Peraturan Menteri Kesehatan Nomor 59 Tahun 2014 Tentang Standar Tarif Pelayanan Kesehatan Dalam Penyelenggaraan Program Jaminan Kesehatan. Indonesia (2016), p. 1-88. [in Bahasa Indonesia]

2. J. Hendrartini, M. Hakimi, Model kinerja dokter dengan pembayaran kapitasi dalam program asuransi kesehatan. [Thesis], Universitas Gadjah Mada (2010). [in Bahasa Indonesia].

3. J. Sundewall, K. Jönsson, C. Cheelo, G. Tomson, Health Policy, 95, 2-3, 122-128 (2010).

4. R. Dewi, Implementasi Pembayaran Kapitasi JKN di Puskesmas Tahun 2014 dan 2015: Perbandingan di Daerah Tertinggal dan Non Tertinggal, Universitas Gadjah Mada, (2016). [in Bahasa Indonesia].

5. H. Akib, Jurnal Ilmiah Ilmu Administrasi Publik, 1, 1 (2012). [in Bahasa Indonesia].

6. A.N. Shihab, Hadirnya Negara di Tengah Rakyatnya Pasca Lahirnya Undang-Undang Nomor 24 Tahun 2011 tentang Badan Penyelenggara Jaminan Sosial (The Presence of the State Among People after The Declaration of Law Number 24 Year 2011 Concerning Social Security Administeri. Indones J Leg [Internet], 9, 2, 175-190 (2012).

7. A. Azwar, Metodologi Penelitian Kedokteran dan Kesehatan Masyarakat. Batam Binarupa Aksara, (2003). [in Bahasa Indonesia].

8. A. Prastowo, Memahami Metode-Metode Penelitian: Suatu Tinjauan Teoritis dan Praktis. Yogyakarta: ar-Ruzz Media, (2011). [in Bahasa Indonesia].

9. K. Buse, N. Mays, G. Walt, Making health policy, UK: McGraw-Hill Education, (2012).

10. P. Boland, The Capitation Sourcebook: A Practical Guide to Managing At-risk Arrangements. Jones \& Bartlett Learning (1996).

11. A. Koduah, H. van Dijk, I.A. Agyepong, BMC health services research, 16, 1, 323 (2016).

12. L. Kullberg, P. Blomqvist, U. Winblad, International journal for equity in health, 17, 1, 123 (2018). 